\title{
A Study on the Constructivism of Contemporary Pottery in China
}

\author{
Hongwu Li \\ Department of sculpture, Academy of Fine Arts, Zhengzhou University Zhengzhou, China
}

Keywords: contemporary; pottery; constructivist form.

Abstract. With the rapid development of economy and society, contemporary pottery in China also forms its unique morphology. This unique morphology has been largely affected by western and modern arts during its formation. To gain a deeper understanding of contemporary pottery in China, the author carries out a specific study on the influence of constructivist form on contemporary pottery creation in China, with a review to bring some inspiration for the innovative development of contemporary pottery in China.

\section{Introduction}

With the rapid development of economy and society, pottery in China begins to break away from its practical functions. As a result, pottery in China goes on a road of pottery development, focused on pure aesthetic plastic art. Compared with traditional pottery in China, the creation language and material use of contemporary pottery have changed a lot. The emergence of these changes has a close relationship with the infiltration of rules of constructivist form. To gain a deep insight into this relationship is the reason why the author carries out a specific study on constructivist form of contemporary pottery in China.

\section{Overview of Contemporary Pottery in China}

The early 1980s can be said to be an embryonic stage of contemporary pottery in China. With the constant innovation and exploration of Chinese artists, it was in the 21st Century that contemporary pottery in China began to break the constraint of traditional pottery. It has also become a new system of art. Compared with developed countries, contemporary pottery in China started and took shape late. But at present, the thoughts and creative concepts of many potters in China have already broken the constraint of pure “modern”. They began to truly reach deep into traditional Chinese cultural deposits and carry out pottery creation, which made contemporary pottery in China bid farewell to past plagiarism, hybridism and hodgepodge and truly go on a unique development road of its own [1].

\section{Cultural Background of Constructivist Phenomenon of Contemporary Pottery in China}

In this paper, to perform an in-depth study, we need to clarify the cultural background of the constructivist phenomenon of contemporary pottery in China and associate literature with actual survey. Our study generalizes this cultural background into two aspects: the influence of Bauhaus' constructivist teaching system and the diversification trend of artistic creation.

The influence of Bauhaus' constructivist teaching system . Currently, the pottery field in China can be divided into two categories, academic pottery and broad pottery. Among them, academic pottery refers to pottery creation in art academies. Central Academy of Fine Arts and Academy of Arts \& Design, Tsinghua University, etc. belong to academic pottery. For academic pottery, Bauhaus' constructivist teaching system has a far-reaching influence. This influence, to a great extent, offers a powerful support for the emergence of contemporary pottery constructivist phenomenon in China [2].

The diversification trend of artistic creation. Apart from Bauhaus' constructivist teaching system, the current diversification trend of artistic creation in China also belong to cultural background of contemporary pottery constructivist phenomenon. Contemporary pottery in China has been edified by the ideology of modern art since it was born. As a result, the development of contemporary pottery is closely related to the development of modern art in China. Mr. Zhu Legeng divided contemporary 
pottery in China into three parts: imitating genres of western modern pottery, innovating on the basis of inheriting tradition, basing on tradition and facing the world. From them, we can easily find the influence of constructivist form, while this influence is closely associated with the diversified creation ways and open mind of contemporary pottery in China [3].

\section{Embodiment of Constructivist Form in Contemporary Pottery Creation in China}

For the embodiment of constructivist form in contemporary pottery creation in China, the author believes that the embodiment mainly include two aspects: contemporary pottery creation and ornament, contemporary pottery modeling.

The application of constructivist form in contemporary pottery creation and ornament in China . For the application of constructivist form in contemporary pottery creation and ornament in China, this application is well-reflected in dot, line and plane ornaments in contemporary pottery ornament in China.

Ornament of dot elements. Dots belong to the most fundamental pottery ornament. The applications of this ornament in contemporary pottery in China can be subdivided into single point, two points, complex points, large and small points and directional point, etc. Tab. 1 shows the applications of these dot elements in contemporary pottery ornament visually.

Tab. 1 The Applications of Dot Elements in Contemporary Pottery Ornament

\begin{tabular}{ll}
\hline Dot Element & \multicolumn{1}{c}{ Characteristic } \\
\hline Single Point & $\begin{array}{l}\text { The grasp of position is the key to single point pottery ornament. } \\
\text { Points above two-third can better ensure attraction to observation and } \\
\text { attention. } \\
\text { Two points can achieve visual movement driven by tension. }\end{array}$ \\
Two Points & $\begin{array}{l}\text { Generally, the closer two points are, the better effect of visual } \\
\text { movement. } \\
\text { The arrangements of different sizes and densities give people endless }\end{array}$ \\
Complex & $\begin{array}{l}\text { imagination } \\
\text { Points }\end{array}$ \\
Large and & $\begin{array}{l}\text { The arrangements of large and small points can convey a sense of } \\
\text { Small Points } \\
\text { sirectional }\end{array}$ \\
Point & $\begin{array}{l}\text { A complex expression form can reflect a sense of direction of the } \\
\text { pottery. }\end{array}$
\end{tabular}

2. Ornament of line elements

Lines elements are characterized by extensibility. This characteristic makes line ornament better serve contemporary pottery ornament in China. Here, the author summaries the applications of line ornament into single line, double line, complex line, curved and broken, long and short, broad and narrow. Tab. 2 shows the applications of line elements in contemporary pottery ornament visually [4].

Tab. 2 The Applications of Line Elements in Contemporary Pottery Ornament

\begin{tabular}{|c|c|}
\hline Line Element & Characteristic \\
\hline Single Line & Create a pottery image using its own segmentation features \\
\hline Double Line & Enrich the visual image of a pottery using its own enhancing effect \\
\hline Complex Line & $\begin{array}{l}\text { Reflect a sense of distance and third dimension of the pottery, } \\
\text { using dense or sparse lines }\end{array}$ \\
\hline $\begin{array}{l}\text { Curved and } \\
\text { Broken }\end{array}$ & Convey the roughness or texture of a pottery \\
\hline $\begin{array}{l}\text { Long and } \\
\text { Short, Broad } \\
\text { and Narrow }\end{array}$ & $\begin{array}{l}\text { Create a sense of space and fluctuation of the pottery, by arranging } \\
\text { long and short lines, broad and narrow lines orderly }\end{array}$ \\
\hline
\end{tabular}

3. Ornament of plane elements 
Plane elements play a role of determining the shape, far better than points and lines. They can be well applied in contemporary pottery ornament. The author summarizes these applications into four parts, discriminability, large and small planes, virtual and physical planes and breakup of planes. Tab. 3 shows the applications of plane elements in contemporary pottery ornament.

Tab. 3 The Applications of Plane Elements in Contemporary Pottery Ornament

\begin{tabular}{c}
\hline Plane Element \\
\hline Discriminability \\
Large and Small \\
Planes \\
Virtual and \\
Physical Planes \\
Breakup of Planes
\end{tabular}

Characteristic

To achieve contemporary pottery ornament using standard abstract and habitual images;

To convey a sense of space, rhythm and tempo of contemporary pottery;

To form and segment a space;

To promote the interest of contemporary pottery, by retaining the original image and features

The application of constructivist form in contemporary pottery modeling in China . For the application of constructivist form in contemporary pottery modeling in China, dots, lines and planes still play an important role. The play of this role, coupled with inspirations of contemporary potters in China, will generally produce excellent works. Foursquare Series shown in Fig. 1 are a representative of the combination between dots, lines, planes and potters' inspirations. From this work, we can feel the beauty of dots, lines and planes visually. Also a strong sense of constructivism in the whole work is conveyed to us without reservation. This belongs to a typical application of constructivist form in contemporary pottery modeling in China [5].

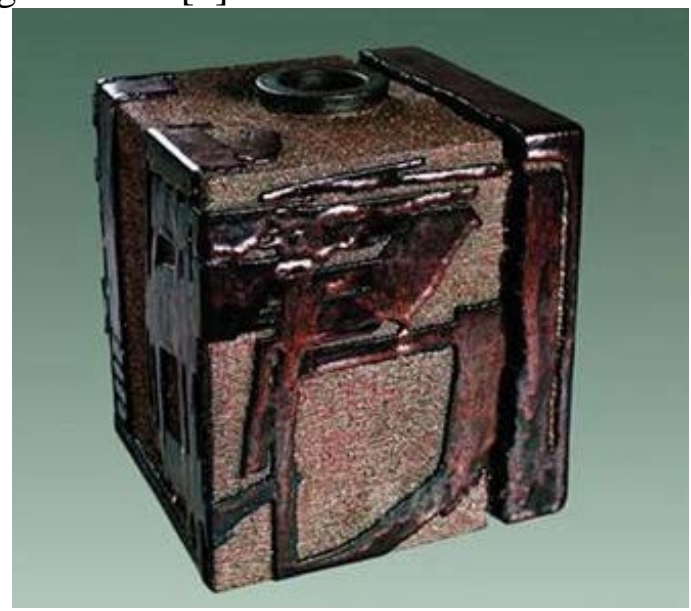

Fig. 1 Foursquare Series (Wang Yaping)

\section{Conclusion}

In the present study on constructivist form of contemporary pottery in China, the author elaborates on the concept of contemporary pottery in China, the cultural background of constructivist phenomenon in contemporary pottery in China and the embodiment of constructivist form in contemporary pottery creation in China. Combined with this series, we can gain a deep insight into the constructivist form of contemporary pottery in China. Hopefully, this knowledge would bring some inspiration for the better development of contemporary pottery in China.

\section{References}

[1]Toll H W, Sullivan A P, Hantman J L. Regional Analysis of Prehistoric Ceramic Variation: Contemporary Studies of the Cibola Whitewares[J]. American Antiquity, 1986, 51(1):204.

[2]Garrison J. Deweyan Pragmatism and the Epistemology of Contemporary Social Constructivism[J]. American Educational Research Journal, 1995, 32(4):716-740. 
[3]Hynek N, Teti A. Saving identity from postmodernism? The normalization of constructivism in International Relations[J]. Contemporary Political Theory, 2010, 9(2):171-199.

[4]Gil-Pérez D, Guisasola J, Moreno A, et al. Defending Constructivism in Science Education[J]. Science \& Education, 2002, 11(6):557-571.

[5]Yin H, Lee C K, Wang W. Dilemmas of Leading National Curriculum Reform in a Global Era: A Chinese Perspective.[J]. Educational Management Administration \& Leadership, 2014, 42(2):293-311. 